\title{
Pengembangan instrumen penilaian portofolio berbasis multiple intelligence untuk mengukur kemampuan berpikir kritis dan sikap ilmiah
}

\author{
Nindi Mediartika ${ }^{1}$ *, Nurfina Aznam ${ }^{2}$ \\ ${ }^{1}$ Program Studi Tadris Kimia, Fakultas Tarbiyah dan Keguruan, Universitas Islam Negeri Mataram \\ Kampus II UIN Mataram Jln. Gajah Mada No.100 Jempong, Mataram, Indonesia \\ ${ }^{2}$ Program Studi Pendidikan Kimia Universitas Negeri Yogyakarta. Jalan Colombo No. 1, \\ Karangmalang, Yogyakarta, 55281, Indonesia. \\ * Corresponding Author: nindimediartika@yahoo.com \\ Received: 12 July 2016; Revised: 11 April 2018; Accepted: 30 April 2018
}

\begin{abstract}
Abstrak
Penelitian ini bertujuan untuk mengetahui karakteristik, kelayakan, dan efektivitas penggunaan instrumen penilaian portofolio berbasis multiple intelligence untuk mengukur kemampuan berpikir kritis dan sikap ilmiah siswa SMA/MA. Prosedur pengembangan menggunakan model 4-D yang dikemukakan oleh Thiagarajan, yaitu define, design, develop, dan disseminate. Hasil penelitian: (1) karakteristik instrumen memiliki tingkat kesukaran pada kisaran -2,00 sampai $+1,41$ dengan reliabilitas pada kisaran 0,00 sampai 0,97 ; (2) instrumen dikatakan layak ditinjau dari validitas isi, empiris, dan reliabilitas; (3) hasil pengukuran kemampuan berpikir kritis siswa SMAN 4 Yogyakarta berada pada kategori sedang dan tinggi dengan kisaran sebesar 34,7\% - 65,3\% dan 72,2\% - 78,8\%, dapat dikatakatan instrumen efektif untuk mengukur kemampuan berpikir kritis siswa; (4) hasil pengukuran sikap ilmiah siswa berada pada kategori sedang dan tinggi dengan kisaran sebesar 36\% $66 \%$ dan $71 \%$ - 94\%, dapat dikatakan instrumen efektif untuk mengukur sikap ilmiah siswa.

Kata Kunci: instrumen penilaian portofolio, multiple intelligence, kemampuan berpikir kritis, sikap ilmiah.

\section{Developing portfolio assessment based on multiple intelligence instrument for measuring critical thinking skills and scientific attitudes}

\footnotetext{
Abstract

This development research aims to find out characteristics, feasibility, and effevtiveness of portfolio assessment based on multiple intelligence instrument for measuring critical thinking skills and scientific attitudes. This developmental study refers to the model suggested by Thiagarajan which is define, design, develop, and disseminate. The results show that: (1) the characteristics of instrumen have good difficulty level $-2,00$ untill $+1,41$ and reliability 0,00 untill 0,97; (2) instrumen is feasible in terms of the contents and empirical validity, and reliabily; (3) the measurement of students's critical thinking skills are in the medium and high category $34,7 \%-65,3 \%$ and $72,2 \%-78,8 \%$, so that an effective instrument used to measure students's critical thinking skills; (4) the measurement of students's scientific attitudes are in the medium and high category $36 \%-65,3 \%$ and $71 \%-94 \%$, so that an effective instrument used to measure students's scientific attitudes.

Keywords: portfolio assessment instrument, multiple intelligence, critical thinking skills, scientific attitude.

How to Cite: Mediartika, N., \& Aznam, N. (2018). Pengembangan instrumen penilaian portofolio berbasis multiple intelligence untuk mengukur kemampuan berpikir kritis dan sikap ilmiah. Jurnal Inovasi Pendidikan IPA, 4(1), 52-63. doi:http://dx.doi.org/10.21831/jipi.v4i1.9973

http://dx.doi.org/10.21831/jipi.v4i1.9973
} 


\section{PENDAHULUAN}

Pembelajaran merupakan serangkaian kegiatan yang merupakan proses interaksi peserta didik dengan pendidik dan sumber belajar pada suatu lingkungan belajar (UU No. 20 Th 2003). Pembelajaran dilakukan oleh siswa dan pendidik dalam upaya penyampaian dan penerimaan ilmu pengetahuan dengan berbagai metode, agar proses pembelajaran dapat dilakukan secara efektif dan efisien untuk mencapai tujuan pembelajaran. Keberhasilan suatu proses pembelajaran dapat dilihat dari ketercapaian tujuan pembelajaran yang telah ditetapkan, untuk mengetahui ketercapaian tersebut perlu diadakannya penilaian dan evaluasi terhadap hasil belajar siswa. Hasil belajar disini dapat mencakup ranah kognitif, psikomotorik, dan afektif.

Pembelajaran itu sendiri menimbulkan interaksi antara guru dan siswa dalam rangka untuk mencapai tujuan pembelajaran dimana guru menyampaikan informasi berupa pengetahuan kepada siswa, sedangkan tujuan yang dimiliki oleh siswa adalah untuk memahami dan menguasai materi yang disampaikan oleh guru. Tujuan pembelajaran kimia di sekolah yaitu untuk memperoleh pemahaman mengenai berbagai hal berupa fakta, mengenal dan memecahkan masalah dimana proses ini menuntut siswa untuk dapat berpikir kritis, memiliki keterampilan dalam penggunaan laboratorium, serta memiliki sikap ilmiah yang dapat ditampilkan dalam kehidupan sehari-hari.

Sistem pendidikan Indonesia saat ini menuntut penilaian kepada siswa secara menyeluruh yang terangkum dalam tiga aspek besar, yaitu aspek kognitif, aspek psikomotorik, dan aspek afektif. Penilaian tidak hanya dilakukan pada setiap akhir pembelajaran, namun yang terpenting yaitu dapat menunjang ketercapaian indikator yang diharapkan.

Salah satu instrumen penilaian yang bisa digunakan dalam proses pembelajaran yaitu instrumen penilaian portofolio, namun penilaian portofolio inipun masih sangat jarang digunakan oleh guru. Salah satu penyebabnya yaitu bentuk portofolio yang masih banyak belum diketahui oleh guru sehingga penggunaannya pun masih belum maksimal dan tahapan dalam melakukan penilaian portofolio ini masih belum berjalan semestinya.

Delgoshaei, Kharrāzi, \& Talkhabi (2012) mendefinisikan "Portfolio is composed of a set of tasks performance by students which provides a clear picture of each student's capabilities, without facing the anxiety of being compared with others or taking tests". Portofolio terdiri dari satu set tugas yang dikerjakan oleh siswa yang akan memberikan gambaran dengan jelas seperti apa kemampuan dari masing-masing siswa, tanpa mengkhawatirkan akan dibandingkan dengan yang siswa lainnya. Penilaian berbasis portofolio (portfolio based assessment) merupakan pendekatan baru yang akhir-akhir ini sering diperkenalkan para ahli pendidikan untuk dilaksanakan di sekolah selain pendekatan penilaian yang telah lama digunakan. Istilah portofolio pertama kali dipergunakan oleh kalangan fotografer dan artis. Melalui portofolio para fotografer dapat memperlihatkan prospektif pekerjaan mereka kepada pelanggan dengan menunjukkan koleksi pekerjaan yang dimilikinya (Widoyoko, 2013, pp. 118-119).

Simon \& Giroux (2000) mendefinisikan "A portfolio is defined as a cumulative and continuous collection of entries selected and reflected on by students in order to assess their competency development" (Singh \& Samad, 2012). Tabatabaei \& Assefi (2012) menyatakan "Among all the procedures of alternative assessment, portfolio has become a popular technique currently". Di antara semua prosedur penilaian alternatif, penilaian portofolio telah menjadi teknik yang populer saat ini. Huang (2012) juga menegaskan "Portfolio assessment is a typical instrumen of the alternative assessment measures". Penilaian portofolio merupakan jenis instrumen penilaian alternatif. Wolf Thomas et al. (2005) menyatakan "Portfolio are essentially different from other forms of assessment in that they make it possible to document the unfolding process of teaching and learning over time". Pada dasarnya penilaian portofolio memiliki bentuk yang berbeda-beda sesuai dengan penilaian yang mungkin dilakukan dalam mendokumentasikan setiap proses dalam pembelajaran.

Siswa memiliki multiple intelligence tentunya dengan tingkat yang berbeda-beda. Sehingga perlu diketahui inteligensi apa saja yang dimiliki oleh setiap siswa dan bagaimana mengembangkannya. Contohnya, pada inteligensi linguistik cara untuk menemukan dan meningkatkan kemampuan inteligensinya yaitu dengan memperbanyak mendengarkan radio atau lebih banyak berlatih berbicara. Begitu juga untuk jenis inteligensi lainnya, telah dipaparkan solusi untuk menemukan dan meningkatkan multiple intelligence manusia. Adapun indikator 
multiple intelligence yang dikembangkan dalam penilaian disesuaikan dengan indikator-indikator pembelajaran dalam ilmu kimia itu sendiri, seperti linguistik verbal, logika matematika, visual spasial, body kinestetik, interpersonal, intrapersonal, dan naturalis.

Kecerdasan dapat dikatakan sebagai kemampuan untuk memecahkan suatu persoalan, kemampuan untuk menciptakan masalah baru untuk dipecahkan dan kemampuan untuk menciptakan sesuatu yang berharga bagi orang lain Widayati \& Widijati (2008, p. 2). Al-Onizat (2016) menyatakan "Multiple intelligence theory posits a set of human intellectual potentials, about eight intelligence, in every individual". Teori kecerdasan majemuk terdiri dari seperangkat potensi intelektual manusia, yang diperkirakan terdiri dari delapan jenis kecerdasan pada setiap individu. Cerruti (2013) menyebutkan "MI's value-based claims did not necessarily impact how teachers actually taught nor how they understood the neurocognitive processes of learning". Penilaian berbasis MI tidak selalu berdampak pada cara guru mengajar atau cara mereka memahami proses pembelajaran neurokognitif.

Tingkat kecerdasan mempengaruhi kemampuan berpikir kritis dan sikap ilmiah yang dimiliki siswa. The American Philosophical Association (Savage \& Wehman, 2014) mendefinisikan berpikir kritis sebagai tujuan penilaian yang reflektif dengan mempertimbangkan alasan dari bukti yang ada, baik dengan metode kontekstual, standar dan konseptualisasi dalam menentukan apa yang harus dipercaya dan apa yang harus dilakukan. Snyder \& Snyder (2008) menambahkan bahwa berpikir kritis merupakan kegiatan mental yang menuntuk siswa untuk berpikir tingkatan yang lebih tinggi, tidak hanya pada tinggkatan menghafal atau menerima begitu saja informasi yang ada tanpa berpikir kritis tentang hal tersebut.

Soleimani, Moinnzadeh, Kassaian, \& Ketabi (2012) menyatakan "Gardner introduces 8 distinct intelligences which include verbal linguistic, logical-mathematical, visual-spatial, bodily-kinesthetic, musical, interpersonal, intrapersonal, and naturalistic". Gardner memperkenalkan 8 jenis kecerdasan yang berbeda, yang meliputi linguistik verbal, logis-matematis, visual-spasial, kinestetik-jasmani, musikal, interpersonal, intrapersonal, dan naturalis. Ekahitanond (2013) menyatakan "Critical thinking is the ability to analyze and evaluate information, and includes attitude, value and character", yang artinya berpikir kritis merupakan kemampuan untuk menganalisis dan mengevaluasi informasi, dan termasuk di dalamnya sikap, nilai dan karakter.

Mapeala \& Siew (2015) menyatakan "Through critical thinking, students can be taught to critically examine different viewpoints on issues concerning the impact of science and technology on everyday life, and evaluate these issues from a societal and environmental perspective". Melalui kegiatan berpikir kritis, siswa dapat diajarkan untuk memeriksa secara kritis dari sudut pandang yang berbeda pada isu-isu mengenai dampak sains dan teknologi dalam kehidupan sehari-hari, dan mengevaluasi isu-isu ini dari perspektif sosial dan lingkungan. Kuhn (Mangiante, 2013) menyebutkan bahwa " $A$ research in the area of cognitive development, studied the nature and acquisition of critical thinking skills and the role that education plays in its development". Peneliti di bidang perkembangan kognitif, mempelajari sifat dan perolehan keterampilan berpikir kritis dan menunjukkan bahwa keterampilan berpikir kritis berperan dalam mengembangkan pendidikan.

Barahal (Brookhart, 2010, p. 4) mendefinisikan "Critical thinking as "artful thinking", which includes reasoning, questioning, and investigating, observing and describing, comparing and connecting, finding complexity, and exploring viewpoint", yang artinya berpikir kritis sebagai "seni berpikir", yang meliputi penalaran, mempertanyakan, dan menyelidiki, mengamati dan menggambarkan, membandingkan dan menghubungkan, menemukan kompleksitas, dan menjelajahi sudut pandang.

Genç (2015) menyebutkan "Attitude plays a more important role in science classes as they involve the teaching of deep and complex concepts". Sikap memainkan peran yang lebih penting di kelas sains karena melibatkan pengajaran konsep dalam dan kompleks. Arseculeratne (2014) mendefinisikan "The scientific attitude is a state of mind that enables creative thinking about Nature and natural phenomena, and engaging in valid scientific research on these phenomena; it is not the same as "attitude to science". Sikap Ilmiah adalah keadaan pikiran yang memungkinkan pemikiran kreatif tentang alam dan fenomena alam, dan terlibat dalam penelitian ilmiah yang valid pada fenomena ini; itu tidak sama dengan "sikap untuk ilmu pengetahuan".

Kumar (2016) menyatakan "In actual fact of scientific attitude is a composite of a number 
of mental habits, or of tendencies to react again and again in certain ways to a novel or problematic situation”. Sebenarnya sikap ilmiah adalah gabungan dari sejumlah kebiasaan mental, atau kecenderungan untuk bereaksi lagi dan lagi dengan cara-cara tertentu untuk sebuah novel atau situasi bermasalah. Olasehinde \& Olatoye (2014) menyatakan "Scientific attitude is the ability to react consistently, rationally and objectively in certain ways to a novel or problematic situation" yang artinya sikap ilmiah adalah kemampuan untuk bereaksi secara konsisten, rasional dan objektif dengan cara-cara tertentu dalam menghadapi suatu permasalahan.

Patil (2011) menyebutkan enam kompetensi dasar sikap ilmiah, yaitu objektivitas, keterbukaan, sesuai fakta, rasa ingin tahu, menangguhkan penilaian, berpikir kritis, dan rasionalitas.

Penggunaan instrumen portofolio yang belum maksimal dalam melakukan penilaian tiga aspek kognitif, afekti, dan psikomotorik pada proses pembelajaran disebabkan karena bentuk dari instrumen penilaian portofolio yang belum banyak diketahui oleh guru, maka perlu dilakukan penelitian dan pengembangan instrumen penilaian portofolio berbasis multiple intelligence untuk mengukur kemampuan berpikir kritis dan sikap ilmiah siswa SMA/MA, dengan bentuk yang lebih baku sehingga memudahkan guru dalam melakukan penilaian menggunakan instrumen penilaian portofolio.

Adapun tujuan penelitian ini adalah untuk mengetahui karakteristik, kelayakan, dan efektivitas penggunaan instrumen penilaian portofolio berbasis multiple intelligence untuk mengukur kemampuan berpikir kritis dan sikap ilmiah siswa.

\section{METODE}

Model yang digunakan pada penelitian ini adalah model penelitian pengembangan (research and development). Model pengembangan yang digunakan adalah model yang diadaptasi dari model pengembangan 4-D (four$D$ model) yang dikembangkan oleh Thiagarajan, Semmel, \& Semmel (1974, pp. 7-9).

Penelitian dimulai sejak penyusunan instrumen yang dikembangkan hingga proses penyebarluasan produk pengembangan. Tahap uji coba skala kecil dan luas dilakukan pada Bulan Januari hingga Maret 2016 di SMAN 4 Yogyakarta. Subjek penelitian siswa kelas XI IPA sebanyak 10 orang untuk uji coba skala kecil dan 34 orang untuk uji coba skala luas.
Prosedur pengembangan yang digunakan dalam penelitian ini terdiri atas empat tahap yaitu Define (pendefinisian), Design (perancangan), Develop (pengembangan), dan Disseminate (penyebaran). Pada tahap pendefinisian, kebutuhan dalam proses pembelajaran ditetapkan dan didefinisikan. Masalah yang perlu diperhatikan dalam menetapkan kebutuhan pembelajaran antara lain kesesuaian kurikulum yang berlaku, tingkat perkembangan siswa, dan kondisi lingkungan sekolah. Selanjutnya dilakukan studi pustaka dan survei lapangan di SMA serta wawancara yang ditujukan kepada guru mata pelajaran kimia di sekolah tersebut. Tujuan dilakukannya tahap ini untuk mencari informasi tentang kondisi, fakta, kesulitan, kendala yang dihadapi siswa dan guru dalam melakukan penilaian portofolio, serta analisis kebutuhan siswa. Di samping itu juga diperlukan informasi tentang jenis penilaian yang sering digunakan di sekolah tersebut.

Pada tahap design, menentukan standar kompetensi, kompetensi dasar, dan indikator keberhasilan, mengembangkan butir-butir evaluasi, mengembangkan dan memilih materi pelajaran untuk pengembangan instrumen penilaian portofolio berbasis multiple intelligence. Selanjutnya, menyusun desain produk instrumen penilaian portofolio berbasis multiple intelligence yang mencakup aspek kemampuan berpikir kritis dan sikap ilmiah siswa SMA. Penyusunan instrumen penilaian portofolio berbasis multiple intelligence dilakukan dengan memperhatikan aspek keterbacaan dan kesesuaian dengan materi untuk tidak menyulitkan guru dan siswa dalam menggunakan instrumen penilaian ini. Penentuan skor penilaian dilakukan dengan menggunakan skala Likert dari skala 1 sampai skala 5.

Selanjutnya tahap develop, Tahap ini diawali dengan menyusun naskah awal instrumen penilaian yang dianalisis dari standar kompetensi ketercapaian. Selanjutnya, instrumen yang telah dikembangkan direview oleh ahli dan uji kelayakan dilakukan oleh para ahli yang sesuai dengan bidang instrumen yang dikembangkan yaitu ahli materi oleh dosen program studi pendidikan kimia dan ahli evaluasi oleh dosen program studi evaluasi pendidikan. Ahli materi melihat cakupan butir yang mengukur kemampuan berpikir kritis dan sikap ilmiah siswa, ahli evaluasi melihat rancangan dan keefektifan kalimat pada lembar observasi dan lembar penilaian diri. Instrumen yang telah divalidasi selanjutnya diujicobakan dalam skala terbatas dengan bantuan lima orang siswa dan 
lima orang guru mata pelajaran kimia yang ditentukan secara purposive sampling atau sampel bertujuan. Instrumen penilaian portofolio berbasis multiple intelligence selanjutnya diujicobakan dalam skala luas yaitu dengan bantuan siswa pada kelas sebenarnya. Hasil dari uji coba skala luas ini nantinya digunakan untuk menentukan reliabilitas instrumen penilaian portofolio berbasis multiple intelligence. Reliabilitas dihitung menggunakan rumusan Kuder-Richardson 21.

Data yang diperoleh dianalisis untuk mengetahui validitas dan koefisien reliabilitasnya. Unidimensional instrumen merupakan ukuran penting untuk mengevaluasi apakah instrumen yang dikembangkan mampu mengukur apa yang seharusnya diukur. Apabila nilai unidimensionalitas lebih dari $20 \%$ maka persyaratan unidimensionalitas terpenuhi (Sumintono \& Widhiarso, 2015, p. 122).

Uji validitas instrumen menggunakan expert judgment. Para pakar mencermati dan memberikan saran untuk perbaikan instrumen penilaian tersebut. Pengujian validitas instrumen dilakukan dengan perhitungan statistik Aiken's $\mathrm{V}$ yang kemudian dikonversi kedalam skala 5 untuk melihat kriteria validitas dari instrumen yang dikembangkan. Data berupa skor dianalisis dengan statistik Aiken's V yang dirumuskan sebagai berikut (Azwar, 2015, p. 113).

$$
\mathrm{V}=\frac{\Sigma s}{[n(c-1)]}
$$

Keterangan:

$\mathrm{V}=$ validitas

$\mathrm{S}=\mathrm{r}-\mathrm{lo}$

$\mathrm{r}$ =angka yang diberikan oleh seorang penilai

lo =angka penilaian validitas yang terendah

c =angka penilaian validitas yang tertinggi

$\mathrm{n}$ =banyaknya penilai

Sedangkan untuk validitas empiris digunakan bantuan program Winsteps pemodelan $R A S C H$. Untuk uji validitas empiris butir soal, hasil yang perlu dilihat untuk melihat butir soal valid dan dapat digunakan, yaitu berdasarkan nilai Outfit Mean Square (MNSQ), Outfit ZStandart (ZSTD), dan Point Measure Correliation (Pt Mean Corr). Adapun kriteria menurut Sumintono \& Widhiarso (2015, p. 81) sebagai berikut.

Nilai $M N S Q$ yang diterima: $0,5<M N S Q<1,5$

Nilai ZSTD yang diterima: $-2,0<Z S T D<+2,0$

Nilai Pt Mean Corr yang diterima: 0,4 $<P t$ Mean Corr $<0,85$
Jika setiap butir soal memenuhi setidaknya dua kriteria di atas, maka butir soal tersebut dapat digunakan, dengan kata lain butir soal tersebut valid. Penguasaan kemampuan berpikir kritis dan sikap ilmiah dibagi menjadi tiga kategori, yaitu tinggi, sedang, dan rendah. Kategori ini di adaptasi dari Azwar (2003, p. 149) seperti yang ditunjukkan pada Tabel 1.

Tabel 1. Kategori Penguasaan Kemampuan Berpikir Kritis dan Sikap Ilmiah

\begin{tabular}{ccc}
\hline No. & Kategori & Persentase Rerata Skor (\%) \\
\hline 1. & Tinggi & $66,67 \% \leq \mathrm{X}$ \\
2. & Sedang & $33,33 \% \leq \mathrm{X}<66,67 \%$ \\
3. & Rendah & $\mathrm{X}<33,33 \%$ \\
\hline
\end{tabular}

Persentase tersebut didapatkan dengan membagi rerata skor pada kemampuan berpikir kritis dan sikap ilmiah dengan jumlah item penilaian. Secara matematis rumusannya dapat ditulis sebagai berikut.

Persentase Penguasaan $=\frac{x}{n} \times 100 \%$

Keterangan:

$\mathrm{x}=$ rerata skor dari kemampuan berpikir kritis dan sikap ilmiah siswa

$\mathrm{n}=$ jumlah item penilaian kemampuan berpikir kritis dan sikap ilmiah

Suatu alat ukur dikatakan mempunyai reliabilitas tinggi atau dapat dipercaya jika alat ukur itu memberikan hasil yang stabil. Estimasi reliabilitas instrumen ditentukan dengan menghitung koefisien korelasi Alpha Cronbach. Perhitungan reliabilitas instrumen dilakukan dengan bantuan aplikasi RASCH Model. Kriteria reliabilitas dapat dilihat pada Tabel 2.

Tabel 2. Kriteria Reliabilitas

\begin{tabular}{ccc}
\hline No. & Nilai Reliabilitas & Kriteria \\
\hline 1. & $0,00 \leq \mathrm{r}<0,50$ & Buruk \\
2. & $0,50 \leq \mathrm{r}<0,60$ & Jelek \\
3. & $0,60 \leq \mathrm{r}<0,70$ & Cukup \\
4. & $0,70 \leq \mathrm{r}<0,80$ & Bagus \\
5. & $0,80 \leq \mathrm{r}<1,00$ & Bagus sekali \\
\hline
\end{tabular}

(Sumintono \& Widhiarso, 2015, p. 85)

Soal dikatakan baik apabila soal tersebut tidak terlalu sulit dan tidak terlalu mudah. Derajat kesukaran soal dianalisis dengan bantuan peogram Winsteps pemodelan $\mathrm{RASCH}$. Kriteria tingkat kesulitan soal diadaptasi dari Sumintono \& Widhiarso (2015, p. 70) dikelompokkan menjadi 4 kategori, yaitu sangat sukar $(+2<b)$, sukar $(\mathrm{b}<+2)$, mudah $(-2<\mathrm{b})$, dan sangat mudah $(\mathrm{b}<-2)$. 


\section{HASIL DAN PEMBAHASAN}

\section{Unidimensionalitas}

Hasil pengukuran raw variance data untuk semua instrumen penilaian di atas 20\% kecuali instrumen penilaian sikap ilmiah pada laporan praktikum materi titrasi asam basa, yaitu $11,1 \%$. Nilai unidimesional di atas $20 \%$, syarat unidimensionalitas terpenuhi yang artinya instrumen yang dikembangkan mampu mengukur apa yang seharusnya diukur.

\section{Validitas Empiris}

Hasil analisis dengan bantuan Program Winsteps Pemodelan $\mathrm{RASCH}$ untuk materi asam basa dari 6 soal uraian yang dikembangkan terdapat 5 soal yang dinyatakan valid, yaitu butir soal nomor $1,2,4,5,6$, dan 1 soal tidak valid yaitu soal nomor 3 karena tidak memenuhi 2 kriteria kevalidan yaitu nilai Outfit MNSQ menunjukkan angka 0,23 atau kurang dari 0,5 dan nilai Pt-Mean Corr sebesar 0,89 atau lebih dari 0,85 . Pada materi titrasi asam basa dari 6 soal uraian yang dikembangkan terdapat 4 soal yang valid, yaitu butir soal nomor 1, 2, 3, 5, dan 2 soal yang tidak valid yaitu soal nomor 4 dan 6 karena tidak memenuhi 2 kriteria kevalidan, yaitu untuk nomor 4 nilai Outfit $M N S Q$-nya menunjukkan angka 1,75 atau lebih dari 1,5 dan nilai Pt-Mean Corr sebesar 0,18 atau kurang dari 0,4 dan soal nomor 6 nilai Outfit MNSQ-nya menunjukkan angka 0,34 atau kurang dari 0,5 dan nilai Pt-Mean Corr sebesar 0,90 atau lebih dari 0,85 . Untuk butir soal yang tidak valid selanjutnya tidak digunakan pada uji skala luas.

\section{Reliabilitas Instrumen}

Hasil analisis reliabilitas item penilaian multiple intelligence dengan bantuan program Winsteps pemodelan RASCH menunjukkan bahwa nilai Alpha Cronbach untuk materi asam basa sebesar 0,95 dan untuk materi titrasi asam basa 0,95. Nilai Alpha Cronbach item penilaian secara keseluruhan kedua materi masuk pada kriteria bagus sekali.

Hasil analisis reliabilitas item penilaian kemampuan berpikir kritis dengan bantuan program Winsteps pemodelan $\mathrm{RASCH}$ menunjukkan bahwa nilai Alpha Cronbach untuk materi asam basa sebesar 0,97 dan untuk materi titrasi asam basa 0,97. Nilai Alpha Cronbach item penilaian secara keseluruhan kedua materi masuk pada kriteria bagus sekali.

Hasil analisis reliabilitas item penilaian sikap ilmiah dengan bantuan program Winsteps pemodelan $R A S C H$ menunjukkan bahwa nilai Alpha Cronbach untuk materi asam basa sebesar 0,92 dan untuk materi titrasi asam basa 0,91. Nilai Alpha Cronbach item penilaian secara keseluruhan kedua materi masuk pada kriteria bagus sekali.

Hasil analisis reliabilitas item penilaian pada angket ini dengan bantuan program Winsteps pemodelan $\mathrm{RASCH}$ menunjukkan bahwa nilai Alpha Cronbach untuk materi asam basa sebesar 0,56 dan 0,56 untuk materi titrasi asam basa. Nilai Alpha Cronbach item penilaian secara keseluruhan kedua materi masuk pada kriteria jelek.

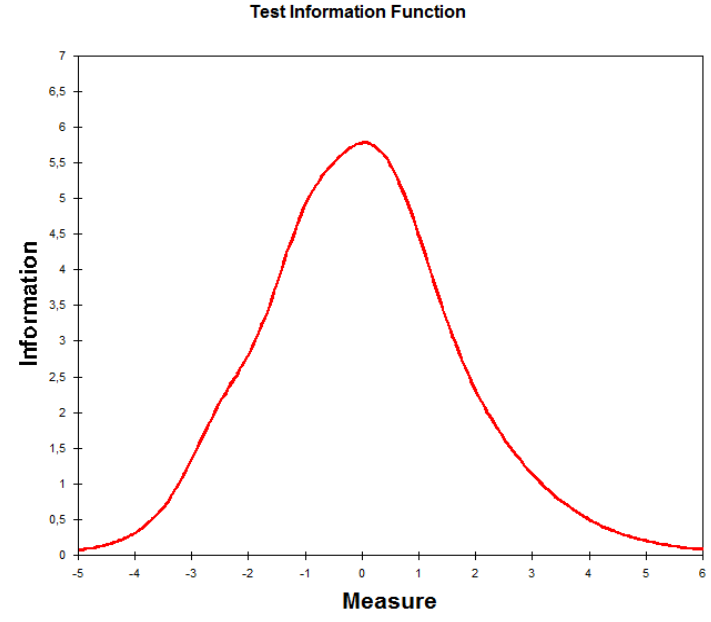

Gambar 1. Grafik Tes Informasi Pengukuran Materi Asam Basa

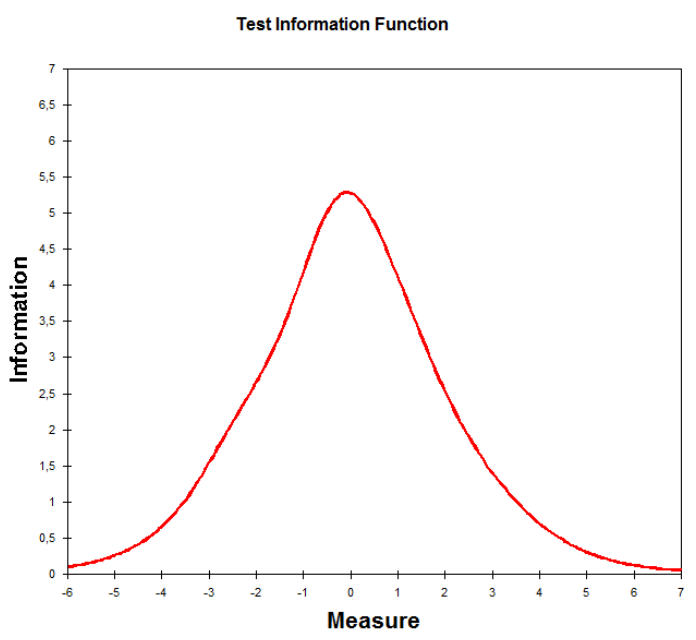

Gambar 2. Grafik Tes Informasi Pengukuran Materi Titrasi Asam Basa

Gambar grafik kurva fungsi informasi pengukuran menunjukkan bahwa set soal yang dikerjakan siswa, baik untuk digunakan pada ujian tes formatif untuk materi asam basa (Gambar 1) dan untuk materi titrasi asam basa 
(Gambar 2). Terlihat pada kurva bahwa pada level abilitas sedang (measure $=0$ ), informasi yang didapatkan oleh pengukuran sangat tinggi. Hal ini menunjukkan bahwa butir soal yang diberikan kepada siswa menghasilkan informasi yang optimal ketika diberikan kepada individu dengan abilitas sedang.

\section{Tingkat Kesukaran}

Tingkat kesukaran butir soal materi asam basa terletak dalam jangkauan -1,84 sampai $+1,41$. Pada item measure terdapat informasi nilai standar deviasi yaitu sebesar 1,05 . Jika nilai standar deviasi ini dikombinasikan dengan ratarata logit dapat dikelompokkan menjadi 4 kelompok soal yaitu soal sangat sukar, sukar, mudah, dan sangat mudah. Adapun soal yang masuk dalam kriteria sangat sukar adalah soal nomor 3, kriteria sukar adalah soal nomor 2 dan 6 , kriteria soal mudah adalah soal nomor 5 dan
1, kriteria soal sangat mudah adalah soal nomor 4.

Untuk tingkat kesukaran butir soal materi titrasi asam basa terletak dalam jangkauan -2,00 sampai $+1,41$. Pada item measure terdapat indofrmasi standar deviasi yaitu sebesar 1,03. Adapun soal yang masuk dalam kriteria sangat sukar adalah soal nomor 6 , kriteria sukar adalah soal nomor 3, 5 dan 1, kriteria soal mudah adalah nomor 2 , dan kriteria soal sangat mudah adalah soal nomor 4 .

Setelah produk instrumen penilaian portofolio berbasis multiple intelligence di uji coba pada skala kecil dan direvisi, selanjutnya produk penilaian diuji coba pada skala luas untuk melihat efektifitas penggunaan produk instrumen untuk mengukur kemampuan berpikir kritis dan sikap ilmiah siswa. Dalam uji coba skala luas yang melibatkan 34 siswa sebagai sampel dalam 1 kelas pada SMAN 4 Yogyakarta yaitu kelas XI IPA 4.

Tabel 3. Komposisi Produk Akhir Instrumen Penilaian Portofolio Kemampuan Berpikir Kritis dan Sikap Ilmiah

\begin{tabular}{|c|c|c|c|c|}
\hline No & Jenis Penilaian & Jenis Evidence & Indikator & Komposisi \\
\hline \multirow[t]{10}{*}{1.} & \multirow{10}{*}{$\begin{array}{l}\text { Kemampuan berpikir } \\
\text { kritis }\end{array}$} & \multirow{2}{*}{$\begin{array}{l}\text { Lembar kerja } \\
\text { siswa }\end{array}$} & a. Memutuskan suatu tindakan & 3 \\
\hline & & & $\begin{array}{l}\text { b. Membuat deduksi dan mempertimbangkan } \\
\text { hasil deduksi }\end{array}$ & 2 \\
\hline & & \multirow{6}{*}{$\begin{array}{l}\text { Laporan } \\
\text { praktikum }\end{array}$} & a. Memfokuskan pertanyaan & 1 \\
\hline & & & b. Menganalisis argumen & 1 \\
\hline & & & $\begin{array}{l}\text { c. Mempertimbangkan kredibilitas suatu } \\
\text { sumber }\end{array}$ & 1 \\
\hline & & & $\begin{array}{l}\text { d. Mengobservasi dan mempertimbangkan hasil } \\
\text { observasi }\end{array}$ & 4 \\
\hline & & & $\begin{array}{l}\text { e. Membuat induksi dan mempertimbangkan } \\
\text { hasil induksi }\end{array}$ & 1 \\
\hline & & & $\begin{array}{l}\text { f. Mendefinisikan istilah dan } \\
\text { mempertimbangkan definisinya }\end{array}$ & 1 \\
\hline & & \multirow[t]{2}{*}{ Tes formatif } & a. Menganalisis argumen & 3 \\
\hline & & & b. Memutuskan suatu tindakan & 3 \\
\hline \multirow[t]{12}{*}{2.} & \multirow[t]{12}{*}{ Sikap ilmiah } & Lembar kerja & a. Jujur & 1 \\
\hline & & \multirow[t]{5}{*}{ siswa } & b. Teliti & 2 \\
\hline & & & c. Disiplin & 2 \\
\hline & & & d. Rasa ingin tahu & 1 \\
\hline & & & e. Berpikir kritis & 1 \\
\hline & & & f. Kerja sama & 1 \\
\hline & & Laporan & a. Jujur & 1 \\
\hline & & \multirow{2}{*}{ praktikum } & b. Disiplin & 1 \\
\hline & & & c. Berpikir kritis & 1 \\
\hline & & \multirow[t]{3}{*}{ Tes formatif } & a. Jujur & 1 \\
\hline & & & b. Ketekunan & 1 \\
\hline & & & c. Berpikir kritis & 1 \\
\hline
\end{tabular}


Jurnal Inovasi Pendidikan IPA, 4 (1), 2018 - 59

Nindi Mediartika, Nurfina Aznam

Tabel 4. Penguasaan Kemampuan Berpikir Kritis Pada Uji Coba Skala Luas

\begin{tabular}{|c|c|c|c|c|}
\hline No & Jenis Evidence & Indikator Kemampuan Berpikir Kritis & $\begin{array}{l}\text { Penguasaan } \\
\text { (\%) }\end{array}$ & Kategori \\
\hline \multirow[t]{2}{*}{1.} & \multirow{2}{*}{$\begin{array}{l}\text { Lembar kerja } \\
\text { siswa }\end{array}$} & \multirow{2}{*}{$\begin{array}{l}\text { a. Memutuskan suatu tindakan } \\
\text { b. Membuat deduksi dan mempertimbangkan hasil } \\
\text { deduksi }\end{array}$} & 72,2 & Tinggi \\
\hline & & & 65,3 & Sedang \\
\hline \multirow[t]{6}{*}{2.} & \multirow{6}{*}{$\begin{array}{l}\text { Laporan } \\
\text { praktikum }\end{array}$} & a. Memfokuskan pertanyaan & 60 & Sedang \\
\hline & & b. Menganalisis argumen & 34,7 & Sedang \\
\hline & & c. Mempertimbangkan kredibilitas suatu sumber & 64,7 & Sedang \\
\hline & & $\begin{array}{l}\text { d. Mengobservasi dan mempertimbangkan hasil } \\
\text { observasi }\end{array}$ & 48,4 & Sedang \\
\hline & & $\begin{array}{l}\text { e. Membuat induksi dan mempertimbangkan hasil } \\
\text { induksi }\end{array}$ & 48,2 & Sedang \\
\hline & & $\begin{array}{l}\text { f. Mendefinisikan istilah dan mempertimbangkan } \\
\text { definisinya }\end{array}$ & 45,3 & Sedang \\
\hline \multirow[t]{2}{*}{3.} & \multirow[t]{2}{*}{ Tes formatif } & a. Menganalisis argumen & 72 & Tinggi \\
\hline & & b. Memutuskan suatu tindakan & 78,8 & Tinggi \\
\hline
\end{tabular}

Tabel 5. Penguasaan Sikap Ilmiah Pada Uji Coba Skala Luas

\begin{tabular}{crlcc}
\hline No. & Jenis Evidence & \multicolumn{1}{c}{ Indikator Sikap Ilmiah } & Penguasaan (\%) & Kategori \\
\hline 1. & Lembar kerja siswa & a. Jujur & 94 & Tinggi \\
& & b. Teliti & 76 & Tinggi \\
& & c. Disiplin & 66 & Sedang \\
& d. Rasa ingin tahu & 56 & Sedang \\
& & e. Berpikir kritis & 71 & Tinggi \\
& & f. Kerja sama & 75 & Tinggi \\
2. & \multirow{2}{*}{ Laporan praktikum } & a. Jujur & 60 & Sedang \\
& & b. Disiplin & 49 & Sedang \\
& & c. Berpikir kritis & 36 & Sedang \\
3. Tes formatif & a. Jujur & 75 & Tinggi \\
& & b. Ketekunan & 79 & Tinggi \\
& & c. Berpikir kritis & 65 & Sedang \\
\hline
\end{tabular}

Uji coba skala luas memanfaatkan waktu 2 jam praktikum untuk materi asam basa, 2 jam praktikum untuk materi titrasi asam basa dan 2 jam pelajaran untuk tes formatif asam basa dan 2 jama pelajaran untuk tes formatif titrasi asam basa. Hasil uji coba ini kemudian digunakan untuk melihat ketercapaian siswa dalam menguasai kemampuan berpikir kritis dan sikap ilmiah. Kemampuan berpikir kritis yang diukur terdiri dari memutuskan suatu tindakan, membuat deduksi dan mempertimbangkan hasil deduksi, memfokuskan pertanyaan, menganalisis argumen, mempertimbangkan kredibilitas suatu sumber, mengobservasi dan mempertimbangkan hasil observasi, membuat induksi dan mempertimbangkan hasil observasi, membuat induksi dan mempertimbangan hasil induksi, mendefinisikan istilah dan mempertimbangkan definisinya, dan membuat penjelasan dari suatu kesimpulan dan hipotesis, sedangkan sikap ilmiah terdiri dari jujur, teliti, disiplin, rasa ingin tahu, berpikir kritis, kerja sama, dan ketekunan. Pemahaman kemampuan berpikir kritis dan sikap ilmiah dibagi menjadi tiga kategori, yaitu tinggi, sedang, dan rendah.

Berdasarkan hasil uji coba skala luas, analisis penguasaan kemampuan berpikir kritis dan sikap ilmiah dilakukan dengan mencari rerata nilai persentase jawaban benar pada masing-masing indikator dari kemampuan berpikir kritis dan sikap ilmiah.

Tingkat penguasaan kemampuan berpikir kritis siswa dari semua indikator penguasan tertinggi berada pada indikator memutuskan suatu tindakan pada evidence tes formatif. Hal serupa juga terlihat pada persentase untuk indikator memutuskan suatu tindakan pada evidence lembar kerja siswa masuk pada kriteria tinggi.

Tingkat penguasaan sikap ilmiah dari semua indikator persentase penguasaan tertinggi berada pada indikator jujur pada evidence lembar kerja siswa. 


\section{Revisi Produk}

Produk instrumen penilaian portofolio berbasis multiple intelligence yang dikembangkan divalidasi oleh satu orang ahli evaluasi, satu orang ahli materi, dan 3 orang guru sebagai pelaksana pembelajaran. Hasil analisis validasi oleh dosen ahli dan guru menunjukkan bahwa instrumen penilaian yang dikembangkan valid atau dengan kata lain instrumen penilaian yang dikembangkan layak untuk digunakan.

Uji coba skala kecil ditujukan untuk melihat nilai unidimensionalitas, validitas butir soal, reliabilitas instrumen, dan tingkat kesukaran soal. Pada uji coba skala kecil nilai unidimensionalitas masing-masing instrumen penilaian telah memenuhi syarat minimal unidimensionalitas $20 \%$ kecuali instrumen penilaian lembar observasi sikap ilmiah untuk laporan praktikum titrasi asam basa, yaitu dengan nilai $11,1 \%$. Uji validitas butir soal diperoleh 5 butir soal uraian yang valid dari 6 butir soal yang diujikan pada tes formatif untuk materi asam basa, sedangkan 4 butir soal uraian yang valid dari 6 butir soal yang diujikan pada tes formatif untuk materi titrasi asam basa.

Reliabilitas instrumen penilaian seperti lembar observasi untuk melihat kemampuan berpikir kritis siswa, tingkat multiple intelligence, sikap ilmiah dan penilaian diri siswa berada pada kriteria lemah, cukup, bagus, bagus sekali dan istimewa jika dilihat dari harga Alpha Cronbach untuk masing-masing instrumen penilaian.

Selanjutnya analisis tingkat kesukaran soal menunjukkan bahwa sebaran soal mulai dari soal dengan tingkat kesulitan yang rendah, sedang dan tinggi. Kurva fungsi informasi pengukuran menunjukkan bahwa soal baik digunakan pada tes formatif. Soal cocok diberikan pada siswa dengan abilitas sedang karena akan memberikan informasi yang optimal.

\section{Kajian Produk Akhir}

Produk instrumen penilaian portofolio berbasis multiple intelligence yang dikembangkan divalidasi oleh satu orang ahli evaluasi, satu orang ahli materi, dan 3 orang guru sebagai pelaksana pembelajaran. Hasil analisis validasi oleh dosen ahli dan guru menunjukkan bahwa instrumen penilaian yang dikembangkan valid atau dengan kata lain instrumen penilaian yang dikembangkan layak untuk digunakan.

Uji coba skala kecil ditujukan untuk melihat nilai unidimensionalitas, validitas butir soal, reliabilitas instrumen, dan tingkat kesukaran soal. Pada uji coba skala kecil nilai unidimensionalitas masing-masing instrumen penilaian telah memenuhi syarat minimal unidimensionalitas $20 \%$ kecuali instrumen penilaian lembar observasi sikap ilmiah untuk laporan praktikum titrasi asam basa, yaitu dengan nilai $11,1 \%$. Uji validitas butir soal diperoleh 5 butir soal uraian yang valid dari 6 butir soal yang diujikan pada tes formatif untuk materi asam basa, sedangkan 4 butir soal uraian yang valid dari 6 butir soal yang diujikan pada tes formatif untuk materi titrasi asam basa.

Reliabilitas instrumen penilaian seperti lembar observasi untuk melihat kemampuan berpikir kritis siswa, tingkat multiple intelligence, sikap ilmiah dan penilaian diri siswa berada pada kriteria lemah, cukup, bagus, bagus sekali dan istimewa jika dilihat dari harga Alpha Cronbach untuk masing-masing instrumen penilaian.

Selanjutnya analisis tingkat kesukaran soal menunjukkan bahwa sebaran soal mulai dari soal dengan tingkat kesulitan yang rendah, sedang dan tinggi. Kurva fungsi informasi pengukuran menunjukkan bahwa soal baik digunakan pada tes formatif. Soal cocok diberikan pada siswa dengan abilitas sedang karena akan memberikan informasi yang optimal.

Berdasarkan hasil validasi dosen ahli dan guru, selanjutnya dilakukan uji validitas secara empiris pada SMAN 4 Yogyakarta yang dalam pembelajaran kimia telah membiasakan siswa untuk melatih kemampuan berpikir kritis. Adapun instrumen yang diujikan secara empiris meliputi soal tes formatif untuk materi asam basa dan tes formatif untuk materi titrasi asam basa, dan lembar observasi untuk menilai kemampuan berpikir kritis, multiple intelligence, sikap ilmiah dan penilaian diri siswa. Dari hasil analisis uji validitas secara empiris diperoleh 5 soal asam basa yang valid dan 4 soal titrasi asam basa yang valid. Nilai Alpha Cronbach untuk masing-masing instrumen lembar observasi menunjukkan bahwa instrumen berada pada reliabilitas cukup, bagus, bagus sekali, dan istimewa.

Kajian produk akhir melalui validasi dosen ahli dan guru, dan validasi empiris menunjukkan bahwa instrumen penilaian portofolio berbasis multiple intelligence telah valid secara teori dan empiris. 
Jurnal Inovasi Pendidikan IPA, 4 (1), 2018 - 61

Nindi Mediartika, Nurfina Aznam

\section{SIMPULAN DAN SARAN}

\section{Simpulan}

Berdasarkan rumusan masalah, tujuan penelitian dan pembahasan hasil penelitian, dapat disimpulkan bahwa instrumen penilaian portofolio berbasis multiple intelligence yang dikembangkan memiliki karakteristik tingkat kesukaran butir soal bervariasi dari sangat sukar, sukar, mudah, dan sangat mudah dengan jangkauan $-1,84$ sampai $+1,41$ untuk materi asam basa dan $-2,00$ sampai $+1,41$ untuk materi titrasi asam basa dan dengan proporsi pada materi asam basa, yaitu $16,67 \%$ butir sangat sukar, 33,33\% butir sukar, 33,33\% butir mudah, dan $16,67 \%$ butir sangat mudah. Proporsi pada materi titrasi asam basa, yaitu $16,67 \%$ butir sangat sukar, $50 \%$ butir sukar, $16,67 \%$ butir mudah, dan $16,67 \%$ butir sangat mudah.

Instrumen penilaian portofolio yang dikembangkan layak digunakan untuk mengukur kemampuan berpikir kritis dan sikap ilmiah berdasarkan hasil validasi dosen ahli evaluasi, dosen ahli materi, penilaian guru kimia dan validasi empiris. Reliabilitas untuk masingmasing instrumen penilaian pada lembar kerja siswa materi asam basa dan titrasi asam basa berturut-turut, yaitu 0,95 dan 0,95 untuk lembar observasi multiple intelligence; 0,97 dan 0,97 untuk lembar observasi kemampuan berpikir kritis; 0,92 dan 0,91 untuk lembar observasi sikap ilmiah; 0,56 dan 0,56 untuk angket penilaian diri. Reliabilitas instrumen penilaian pada laporan praktikum materi asam basa dan titrasi asam basa, yaitu 0,85 dan 0,48 untuk lembar observasi multiple intelligence; 0,81 dan 0,71 untuk lembar observasi kemampuan berpikir kritis; 0,87 dan 0,00 untuk lembar observasi sikap ilmiah. Reliabilitas untuk masing-masing instrumen penilaian pada tes formatif materi asam basa dan titrasi asam basa, yaitu 0,92 dan 0,93 untuk lembar observasi multiple intelligence; 0,78 dan 0,55 untuk lembar observasi kemampuan berpikir kritis; 0,63 dan 0,63 untuk lembar observasi sikap ilmiah; 0,00 dan 0,48 untuk angket penilaian diri.

Hasil pengukuran kemampuan berpikir kritis siswa menunjukkan bahwa penguasaan kemampuan berpikir kritis siswa pada SMAN 4 Yogyakarta untuk setiap aspek penilaian berada pada kategori sedang dengan kisaran pencapaian sebesar 34,4\% - 63,5\% dan kategori tinggi pada kisaran pencapaian $67,1 \%$ - 85,9\%. Dari hasil pengukuran juga dapat diketahui kemampuan berpikir kritis siswa secara individu sehingga diperoleh informasi yang lebih akurat mengenai kemampuan berpikir kritis siswa. Dengan demikian dapat diartikan bahwa instrumen penilaian portofolio yang dikembangkan efektif digunakan untuk mengukur kemampuan berpikir kritis.

Hasil pengukuran sikap ilmiah siswa menunjukkan bahwa penguasaan sikap ilmiah siswa pada SMAN 4 Yogyakarta untuk setiap aspek penilaian berada pada kategori sedang dengan kisaran pencapaian sebesar 43,53\% $66,71 \%$ dan kategori tinggi pada kisaran pencapaian $71,76 \%$ - 96,76\%. Dari hasil pengukuran juga dapat diketahui sikap ilmiah siswa secara individu sehingga diperoleh informasi yang lebih akurat mengenai sikap ilmiah siswa. Dengan demikian dapat diartikan bahwa instrumen penilaian portofolio yang dikembangkan efektif digunakan untuk mengukur sikap ilmiah siswa.

\section{Saran}

Saran yang dapat diberikan terkait dengan pengembangan produk instrumen penilaian portofolio berbasis multiple intelligence antara lain: (1) Guru dapat menggunakan produk instrumen penilaian portofolio berbasis multiple intelligence ini untuk mengukur kemampuan berpikir kritis dan sikap ilmiah siswa pada mata pelajaran kimia materi asam basa dan titrasi asam basa. (2) Produk akhir dari instrumen penilaian portofolio berbasis multiple intelligence ini diharapkan dapat digunakan sebagai contoh permodelan oleh guru kimia untuk mengembangkan instrumen pengukuran kemampuan berpikir kritis dan sikap ilmiah siswa.Saran dapat berupa masukan bagi peneliti berikutnya, dapat pula rekomendasi implikatif dari temuan penelitian.

\section{DAFTAR PUSTAKA}

Al-Onizat, S. H. (2016). Measurement of multiple intelligences among sample of students with autism, and intellectual disability using teacher estimation and its relationship with the variables: The type and severity of disability, gender, age, type of center. International Journal of Education ISSN, 8(1), 107-128. https://doi.org/10.5296/ije.v8i1.8268

Arseculeratne, S. (2014). Education in medicine as a component of modern science; restoring the balance. Anuradhapura Medical Journal, 8(2), 45. https://doi.org/10.4038/amj.v8i2.7526

Azwar, S. (2003). Penyusunan skala psikologi. 
Yogyakarta : Pustaka Pelajar. https://doi.org/2003

Azwar, S. (2015). Reliabilitas dan validitas. Yogyakarta: Pustaka Pelajar.

Brookhart, S. M. (2010). How to assess higherorder thinking skills in your classroom. ASCD.

Cerruti, C. (2013). Building a functional multiple intelligences theory to advance educational neuroscience. Frontiers in Psychology, 4, 950. https://doi.org/10.3389/fpsyg.2013.00950

Delgoshaei, Y., Kharrāzi, K., \& Talkhabi, M. (2012). The impact of portfolio evaluation method on the development of children's reading skills. Procedia - Social and Behavioral Sciences, 32, 356-360. https://doi.org/10.1016/J.SBSPRO.2012.0 1.053

Ekahitanond, V. (2013). Promoting university students' critical thinking skills through peer feedback activity in an online discussion forum. Alberta Journal of Education Research, 59(2). Retrieved from http://www.ajer.ca/

Genç, M. (2015). The effect of scientific studies on students' scientific literacy and attitude. Ondokuz Mayls Üniversitesi Eğitim Fakültesi Dergisi, 34(1), 141-152. https://doi.org/10.7822/OMUEFD.34.1.8

Huang, J. (2012). The implementation of portfolio assessment in integrated english course. English Language and Literature Studies, 2(4), 15. https://doi.org/10.5539/ells.v2n4p15

Kumar, S. R. (2016). Evaluation of scientific attitude among student teachers. Indian Streams Research Journal, 6(1). Retrieved from http://oldisrj.lbp.world/Article.aspx?Articl eID $=9206$

Mangiante, E. S. (2013). Planning science instruction for critical thinking: Two urban elementary teachers' responses to a state science assessment. Education Science, 3, 222-258. https://doi.org/10.3390/educsci3030222

Mapeala, R., \& Siew, N. M. (2015). The development and validation of a test of science critical thinking for fifth graders. SpringerPlus, $4(1), \quad 741$. https://doi.org/10.1186/s40064-015-1535-
0

Olasehinde, K. J., \& Olatoye, R. A. (2014). Scientific attitude, attitude to science and science achievement of senior secondary school students in Katsina State, Nigeria. Journal of Educational and Social Research, 4(1), 445. Retrieved from http://www.mcser.org/journal/index.php/j esr/article/view/1862

Patil, G. V. (2011). A comparative study os scientific attitude about secondary and higher secondary level students. International Referred Research Journal, II.

Savage, M. P., \& Wehman, T. L. (2014). Assessing the impact of international experiential education on the critical thinking skills and academic performance of college students. International Journal of Arts \& Sciences, 7(1), 1.

Singh, C. K. a/p S., \& Samad, A. A. (2012). The use of portfolio as an assessment tool in the Malaysian L2 classroom. International Journal of English Language Education, 1(1), 94-108. https://doi.org/10.5296/ijele.v1i1.2851

Snyder, L. G., \& Snyder, M. J. (2008). Teaching critical thinking and problem solving skills. The Journal of Research in Business Education, 50(2), 90.

Soleimani, H., Moinnzadeh, A., Kassaian, Z., \& Ketabi, S. (2012). The effect of instruction based on multiple intelligences theory on the attitude and learning of general English. English Language Teaching, 5(9), 45. https://doi.org/10.5539/elt.v5n9p45

Sumintono, B., \& Widhiarso, W. (2015). Aplikasi pemodelan rasch pada assessment pendidikan. Cimahi: Trim Komunikata.

Tabatabaei, O., \& Assefi, F. (2012). The effect of portfolio assessment technique on writing performance of EFL learners. English Language Teaching, 5(5), 138. https://doi.org/10.5539/elt.v5n5p138

Thiagarajan, S., Semmel, D. S., \& Semmel, M. I. (1974). Instructional development for training teachers of exceptional children: A sourcebook. Blomington: may be ordered from the Council for Exceptional Children. 


\section{Jurnal Inovasi Pendidikan IPA, 4 (1), 2018 - 63}

Nindi Mediartika, Nurfina Aznam

Thomas, C., Britt, P., Blackbourn, J. M., Blackbourn, R., Papason, B., Tyler, J. L., \& Williams, F. K. (2005). Portfolio assessment: a guide for teachers and administrators. NATIONAL FORUM OF EDUCATIONAL ADMINISTRATION AND SUPERVISION JOURNAL, 23(4), 1-8. Retrieved from http://www.nationalforum.com/Electronic Journal Volumes/Thomas, Conn-Portfolio Assessment A Guide For Teachers And
Administrator.pdf

Widayati, S., \& Widijati, U. (2008). Mengoptimalkan 9 zona kecerdasan majemuk anak. Yogyakarta: Luna Publisher.

Widoyoko, S. E. P. (2013). Evaluasi program pembelajaran: panduan praktis bagi pendidik dan calon pendidik. Yogyakarta: Pustaka Pelajar. https://doi.org/2013 